\title{
Margaret McCartney: Optional disclosure of payments is pointless
}

\author{
Margaret McCartney general practitioner
}

Glasgow

Naked, luscious transparency! Hurrah! The Association of the British Pharmaceutical Industry (ABPI) is about to reveal, ladies and gentlemen, the pounds and pence that the industry has paid to healthcare professionals, along with their names. The obfuscatory kit of amalgamated payments and anonymity is coming off.

But this is all being done with the recipients' consent, so the entire charade has all the thrust of a dead jellyfish. Doctors can opt out, meaning that a key opinion leader can earn hundreds of thousands of pounds while influencing patients, colleagues, formularies, and policies - and we won't know. Owing, we are told, to data protection issues (ie, consent is required for sharing), transparency is not compulsory.

Worse, revealing a little may entice us to assume that we've seen a lot, including all of the important bits, when we have not. Neither can this be a definitive list of conflicts of interest: they're not all about pharma. Private practice, patent ownership, or contracts to the quality and outcomes framework can adversely affect the way we work, what we do, and why we do it.

Because compulsory declared interests would need the General Medical Council to have new powers requiring an act of parliament, we won't get a full list any time soon. And transparency only shows the problems: should people who take thousands of pounds from industry as "thought leaders" sit on national guideline panels or help set government policy?

The relation between pharma and the NHS has ratcheted up several gears while we've all been worrying about the right amount of consent on transparency.

Should people who take thousands of pounds from industry as "thought leaders" sit on national guideline panels or help set government policy?

Let's rewind: not too long ago, a past president of the ABPI said that "the conservatism of British doctors borders on Luddism" and that "there should be an obligation for GPs to take up new drugs as soon as they are approved. Doctors' rewards should be linked to their prescription record."1
Ten years on, we have the reality: "We have to build a 21 st century healthcare innovation economy in which our NHS is pumping alongside our industry supporting it," ${ }^{2}$ says George Freeman, who is minister for life sciences and responsible for the National Institute for Health and Care Excellence. Is the NHS being pimped to pharma?

The new arrangements for joint working in place since 2012, promoted by the Department of Health, the NHS, and the ABPI, seek to "increase shareholder value" through "more proactive treatment and management of patients," through "optimal numbers of appropriate patients receiving treatment." ${ }^{3}$ But clinical trials remain unpublished, ${ }^{4}$ and industry sponsored trials are biased towards their own products. ${ }^{5}$

I wrote last year about pharma paying pharmacists to review patient records to make treatment recommendations despite individual patients not having given permission for access: what new world have we wandered into ${ }^{6}$ We need cast iron divisions between healthcare and industry that recognise their differences in priority. Doctors who want to act as thought leaders for, or advisers to, pharma should have to be fully open about conflicts of interest to avoid undue influence.

Competing interests: See www.bmj.com/about-bmj/freelancecontributors/margaret-mccartney.

Provenance and peer review: Commissioned; not externally peer reviewed.

thebmj.comNews Doctors getting biggest payments from drug companies don't declare them on new website (BMJ 2016;354:i3679, doi:10.1136/bmj.i3679)

McCartney M. Great shoes, now about this new drug. Financial Times 2005 Aug 6. http: //on.ft.com/29esJxu.

2 Robinson T. Pharmafile. 1 Feb 2014. UK pharma is vital for our landscape. www. pharmafile.com/news/195905/george-freeman-uk-pharma-vital-our-landscape.

Department of Health. NHS, ABPI. Moving beyond sponsorship. https://www.networks. Department of Health. NHS, ABPI. Moving beyond sponsorship. https://www.networks.
nhs.uk/nhs-networks/joint-working-nhs-pharmaceutical/documents/joint\%20working\% 20toolkit\%20dh.abpi.pdf.

4 Ross JS, Tse T, Zarin DA, Xu H, Zhou L, Krumholz HM. Publication of NIH funded trials registered in ClinicalTrials.gov: cross sectional analysis. BMJ 2012;344:d7292. doi:10. 1136/bmj.d7292 pmid:22214755.

5 Lundh A, Sismondo S, Lexchin J, Busuioc OA, Bero L. Industry sponsorship and research outcome. Cochrane Database Syst Rev 2012;12:MR000033.pmid:23235689. 
6 McCartney M. Partnerships: pharma is closer than you think. BMJ 2015;351:h3688. doi: 10.1136/bmj.h3688 pmid:26206956.
Published by the BMJ Publishing Group Limited. For permission to use (where not already granted under a licence) please go to http://group.bmj.com/group/rights-licensing/ permissions 